\title{
BONE REGENERATION AFTER DEMINERALIZED BONE MATRIX AND CASTOR OIL (RICINUS COMMUNIS) POLYURETHANE IMPLANTATION
}

\author{
Fábio Renato Manzolli LEITE ${ }^{1}$, Lizeti Toledo de Oliveira RAMALHO²
}

1- DDS, MSc, Graduate student, Department of Diagnosis and Surgery, Dental School of Araraquara, São Paulo State University, Araraquara, SP, Brazil.

2- DDS, MSc, PhD, Full Professor, Department of Morphology, Dental School of Araraquara, São Paulo State University, Araraquara, SP, Brazil.

Corresponding address: Dr. Fábio Renato Manzolli Leite - Av. Altino Correia de Almeida Moraes, 122 - Araraquara-SP - 14801-080. Phone: 5516 3301-6510 - Fax: 5516 3301-6369 - e-mail: leite.fabio@gmail.com

Received: May 18, 2007 - Modification: August 13, 2007 - Accepted: December 03, 2007

\begin{abstract}
I nnocuous biocompatible materials have been searched to repair or reconstruct bone defects. Their goal is to restore the function of live or dead tissues. This study compared connective tissue and bone reaction when exposed to demineralized bovine bone matrix and a polyurethane resin derived from castor bean (Ricinus communis). Forty-five rats were assigned to 3 groups of 15 animals (control, bovine bone and polyurethane). A cylindrical defect was created on mandible base and filled with bovine bone matrix and the polyurethane. Control group received no treatment. Analyses were performed after 15, 45 and 60 days ( 5 animals each). Histological analysis revealed connective tissue tolerance to bovine bone with local inflammatory response similar to that of the control group. After 15 days, all groups demonstrated similar outcomes, with mild inflammatory reaction, probably due to the surgical procedure rather than to the material. In the polymer group, after 60 days, scarce multinucleated cells could still be observed. In general, all groups showed good stability and osteogenic connective tissue with blood vessels into the surgical area. The results suggest biocompatibility of both materials, seen by their integration into rat mandible. Moreover, the polyurethane seems to be an alternative in bone reconstruction and it is an inexhaustible source of biomaterial.
\end{abstract}

Key words: Bone regeneration. Ricinus communis. Bone substitutes.

\section{INTRODUCTION}

During the last decade, several segments of health fields have searched for biocompatible materials innocuous to the organism to repair or reconstruct bone defects. Their goal is to replace live or dead tissue that has no function anymore by a functional one.

A biomaterial must be compatible with the implantation site, atoxic, non carcinogenic, chemically and biologically stable, and have an adequate density, weight, mechanical resistance and elasticity. Also, these materials need to have similar physical performance when compared to the original tissue. Some examples are inert metals, ceramics and polymers ${ }^{5,15}$. Among polymers, the materials in evidence are polytetrafluoroethylene, polyethylene, polyester and silicon. The challenge is to find out a polymer that has no harmful residues and stands inert when in contact with tissues.

In recent years the osteogenic potential of demineralized bovine bone matrix implants has stimulated researches based on the hypothesis that mesenchymal cells can suffer differentiation into osteoblasts and chondroblasts for new bone formation. Additionally, this material mechanically deters part of connective tissue penetration into the surgical site 1,8, $9,11,16^{\text {. }}$

The best biomaterial is the autogenous bone grafting because is plenty of immunocompatible cells for osteogenesis. However, in this case, two surgical sites are required and the source of bone is limited ${ }^{4}$. The demineralized bovine bone matrix is a great source of grafting material and its almost neutral $\mathrm{pH}$ helps the fracture healing process during the first week. During bone repair, the local pH decreases assisting the decalcification, resorption and remodeling of necrotic bone that result from trauma. Moreover, the demineralized bone chemical composition, structure and porosity are almost identical to that of the human bone properties, thus preventing microfractures between the grafted material and the surgical site sin, $^{2,14}$.

Some studies have shown that the polyurethane derived 
from Ricinus communis has potential to be employed in many cases, such as bone prosthesis, alveolar healing and plastic surgery ${ }^{8,9}$. This polymer is composed by fatty acid and diphenylmethane diisocyanate, which are thought to be recognized by the organism as body component rather than a foreign substance.

The purpose of this study was to compare the differences in connective and bone tissue reaction of rat mandibles when exposed to demineralized bovine bone matrix and polyurethane resin derived from castor bean (Ricinus communis).

\section{MATERIAL AND METHODS}

Forty-five adult male Holtzman rats weighing 250 to $300 \mathrm{~g}$ were used in the experiment. Food and water was available ad libitum. During the whole experiment, the animals were housed one to a cage. After 3 days of surgery, the animals had a maize flour and water diet to avoid local trauma on surgical site.

Animals were anesthetized with an intramuscular injection of ketamine (Francotar ${ }^{\circledR}$; VIRBAC ${ }^{\circledR}$, São Paulo, $\mathrm{SP}$, Brazil) at a dose of $0.08 \mathrm{~mL} / 100 \mathrm{~g}$ associated to xylazine chloride $\left(\right.$ Virbaxyl $^{\circledR}$; VIRBAC ${ }^{\circledR}$ ) at $0.04 \mathrm{~mL} / 100$ g. Trichotomy was performed on mandible base. An incision on longitudinal (anteroposterior) direction was followed by skin and periosteum divulsion. After mandible base exposure, a cylindrical bone defect $(7 \times 2 \times 2 \mathrm{~mm})$ was created with an ace cylindrical bur number 58 (KG Sorensen ${ }^{\circledR}$, Barueri, SP, Brazil). All procedures were carried out under copious saline irrigation. Defect was filled with particles of Ricinus communis resin (Department of Analytical Chemistry and Polymers Technology, University of São Paulo, São Carlos, SP, Brazil) and bovine demineralized bone matrix (Gen-Tech ${ }^{\circledR}$, BAUMER $^{\circledR}$, Mogi Mirin, SP, Brazil). Both substances were mixed to the animal blood in a sterile glass plate (Corning ${ }^{\circledR}$, São Paulo, SP, Brazil). Sutures were made using polyglactin 4-0 thread (Vicryl ${ }^{\circledR}$, Johnson \& Johnson $^{\circledR}$, São José dos Campos, SP, Brazil).

Animals were assigned to 3 groups: Control (C): 15

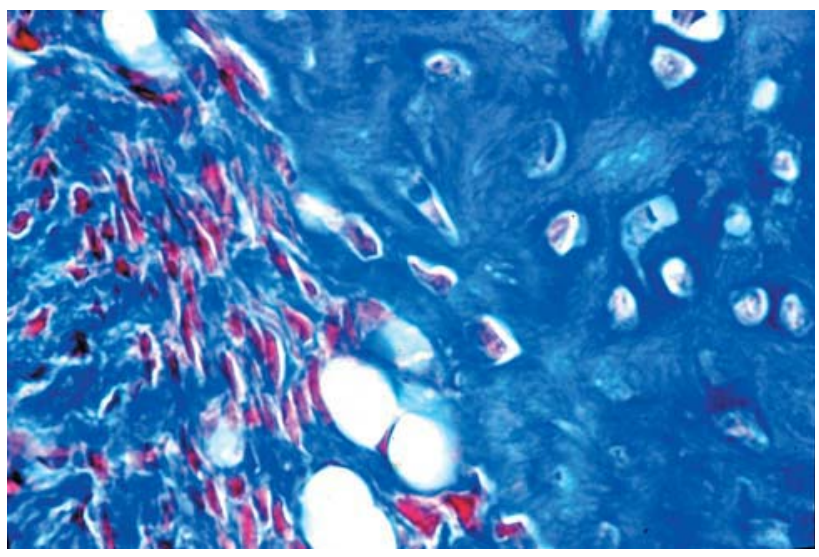

FIGURE 1- 15 days - control group. Collagen fibers randomly arranged characterizing an embryonic bone. (M.T., original magnification $\mathrm{x} 400$ ) animals with no bone defect filling; Ricinus communis group (RC): 15 animals that had their defects filled with Ricinus communis polyurethane particles mixed to the animal blood; Bovine bone group (BB): 15 animals that had their defects filled with demineralized bovine bone matrix particles mixed to the animal blood.

After 15, 45 and 60 days of implantation animals were killed by anesthetic overdose followed by mandible removal, immersion in $10 \%$ formalin for $48 \mathrm{~h}$ and block biopsy preparation. Blocks were fixed, decalcified and embedded in paraffin. Six-micrometer horizontal sections were cut through the defects, stained with hematoxylineosin (H.E.), Picro Sirius red (P.S.) and Masson Trichrome (M.T.) and subjected to light microscopic examination.

\section{RESULTS}

\section{Control group}

Tissue analysis showed collagen fibrils randomly disposed after 15 days. Embryonic tissue filled the defect where recently formed collagen fibrils were surrounded by osteoblasts characterizing an early woven (embryonic) bone (Figure 1). At 45 days, an osteocytes-rich immature bone could be seen. This tissue was characterized by the presence of several osteocytes inside the bone matrix, which was surrounded by osteoblasts. Also, the large number of bone lamellae was surrounded by a fine-fibered connective tissue. 60-day defects showed coarse-fibered woven bone under substitution by a mature lamellar bone (Figure 2).

\section{Ricinus communis group}

Along the early 15 days, the group presented hyaline cartilage in its periphery, also called primary spongiosa (Figure 3). A fine-fibered connective tissue could be seen surrounding the polyurethane particles. After 45 days, collagen fibers were under maturation process, changing its structural form to begin lamellae formation denoted by nucleus of organic bone matrix formation (Figure 4). After 60 days, few polyurethane particles were still surrounded

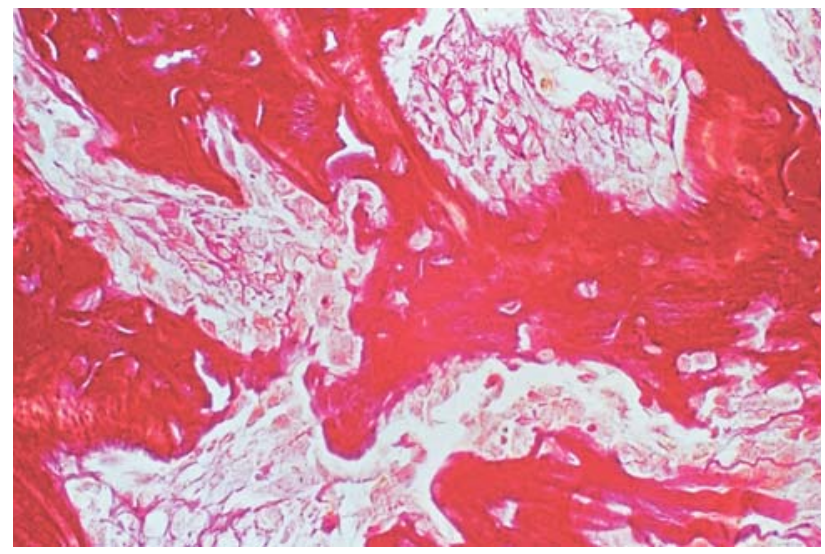

FIGURE 2- 60 days - control group. Woven bone surrounded by osteoblasts (P.S., original magnification, $\mathrm{x} 200$ ) 
by multinuclear clastic cells. Inside the polyurethane pores, connective tissue was present showing areas of bone neoformation without clasts that were localized externally (Figure 5).

\section{Bovine bone group}

After 15 days, defects that received demineralized

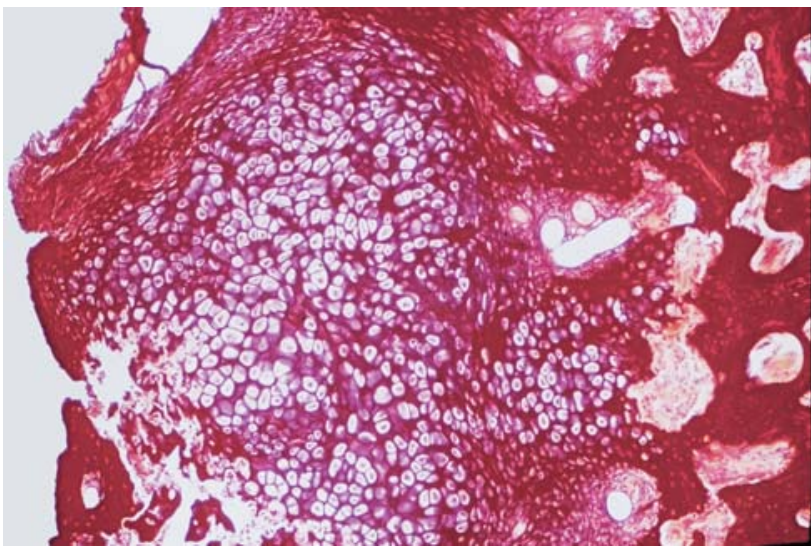

FIGURE 3- 15 days - RC group. Reparative cartilage formation and substitution by bone matrix (P.S., original magnification, $\mathrm{x} 100$ )

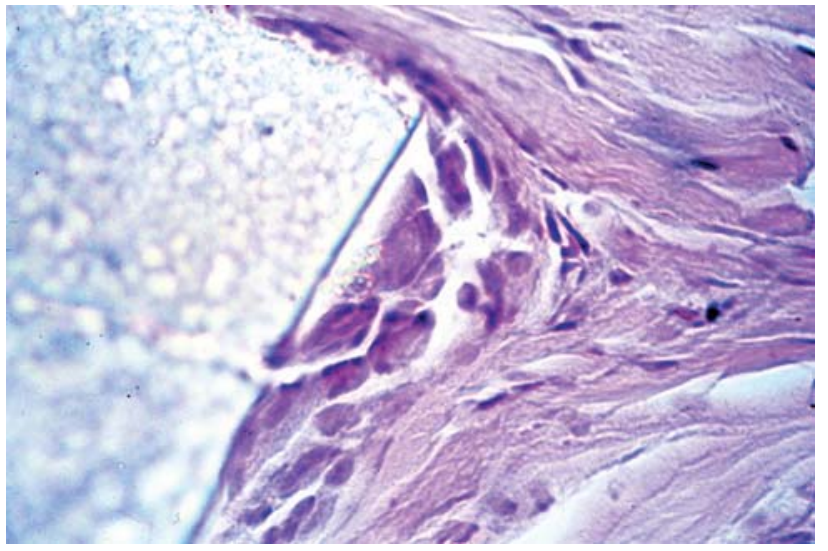

FIGURE 5- 60 days - RC group. Polymer particle surrounded by clastic cells (H.E., original magnification, $x 400$ )

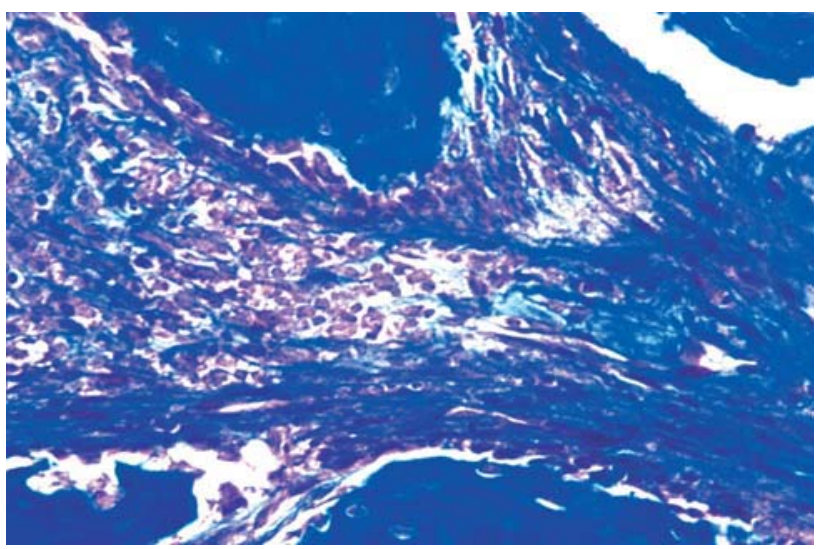

FIGURE 7- 45 days, BB group. Coarse-fibered connective tissue. Note the collagen fibers network (M.T., original magnification, x200) bovine bone particles showed osteoclasts in its periphery, characterizing the beginning of the absorption process. In this period, the osseous defect was covered by a coarsefibered connective tissue and collagen fibers randomly disposed surrounded by fibroblasts. In some places inside this connective tissue an embryonic bone matrix rich in osteocytes and extensive bone marrow spaces could be

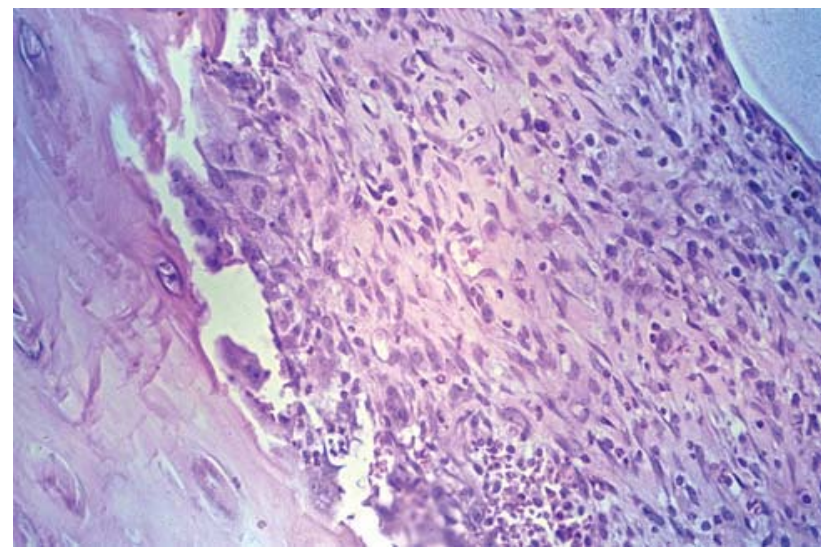

FIGURE 4- 45 days RC group. Coarse-fibered connective tissue formed. Cell differentiation into osteoblasts (H.E., original magnification, $\mathrm{x} 200$ )

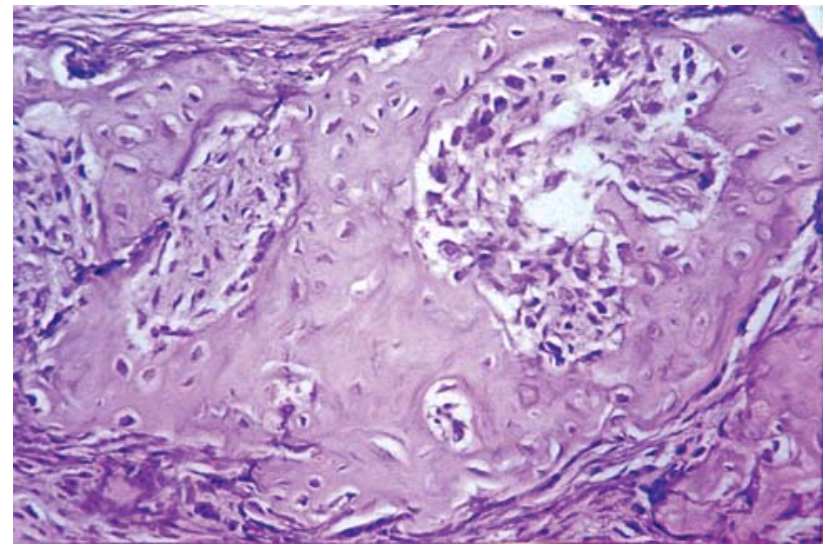

FIGURE 6- 15 days BB group. High concentration of collagen fibers (H.E., original magnification, x200)

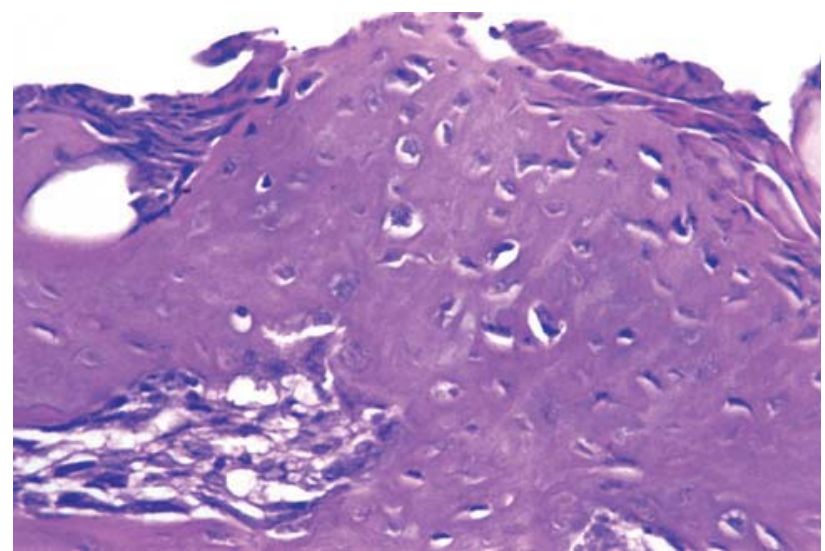

FIGURE 8- 60 days, BB group. Woven bone filling almost the whole defect (H.E., original magnification, $x 200)$ 
seen surrounded by a line of active osteoclasts (Figure 6). Bone islands still under formation characterized the 45 day period. This connective tissue showed great amount of organized collagen fibers indicating bone tissue replacement (Figure 7). At 60 days, the result was a coarsefibered woven bone being replaced by a secondary lamellar one (mature bone) in centripetal direction from margins, but in some isolated points inside the matrix this process could be observed too (Figure 8).

\section{DISCUSSION}

In the last decade, several materials have been studied in order to find one capable of replacing the lost bone tissue due to resorption, mutilation, traumas and so on. Bone formation can occur by three processes: osteogenesis, osteoinduction and osteoconduction. Osteogenesis occurs with transplant of autogenous osteoblasts and mesenchymal cells; osteoconduction occurs when the implanted material serve as passive scaffold that is absorbed and replaced by bone (creeping substitution); and osteoinduction needs some osteoprogenitor cells derived from stimulated perivascular mesenchymal cells, also called pleuripotent stem cells ${ }^{1,16}$. Most of the process observed in this study was due to osteoconduction.

Grafting of autogenous bone remains the best option for bone replacement. However, its achievement causes more morbidity and represents a limited source. This way, some different categories of materials have been developed and are under test for bone substitution, such as bioactive glass, calcium sulphate, ceramics (i.e., hydroxyapatite) and polymers. In this investigation, the bone defects in the BB group were filled by newly formed trabeculae after 15 days, an observation that is consistent with the results of previous studies $^{6,12}$. This biomaterial is largely employed and, because of that, was chosen to be compared to polyurethane.

In the microscopic analysis, the amount of connective tissue decreased and the number of osseous trabeculae raised gradually in both experimental groups ${ }^{2,10}$. Two possible benefits of a faster bone formation are the decrease of soft tissue penetration into the surgical area and the formation of a scaffold for cell proliferation.

Inflammatory response observed during the first few days after surgery in all groups seemed to be related to the surgical trauma and has been cited by other authors since $1987^{11}$. Along the experimental period, the exogenous materials were recognized and an elevated clastic cell concentration could be seen around their borders, indicating material resorption.

In summary, both materials influenced positively new bone formation and osteoconduction was the process observed for regeneration. Centripetal bone regeneration could be seen, with new bone formation from the periphery of the defect towards the center. This fact is important once it is the difference from osteoconduction and osteoinduction; in the latter multi-ossification sites are observed.

In some experimental and clinical investigations, in the same way as in the present one, it was observed that the bovine demineralized bone matrix helps the healing process to form a normal bone with high cellularity and vascular vessels $^{13,17}$.

Any substance implanted into biological tissues causes a response. The extension, duration and severity of this response determine if a material is biocompatible or not. In the case of intra-osseous implants, it is expected that the material establishes a direct contact with the surrounding bone. However, during the initial stages after implantation, the biomaterial can establish a fiber-osseous integration with the surrounding bone. This indirect contact can alter the long-term stabilization of the implant ${ }^{7}$.

Ricinus communis polyurethane had an excellent acceptance by the surrounding tissues, with no permanent capsule formation, consolidation of the interface between bone/material and no toxicity, as reported by Konig Junior, et al. ${ }^{7}$ (1999). However, after 60 days, clastic cells could still be observed around small polyurethane granules, perhaps because of the very different sizes of the polymer particles that were not standardized in that time by the manufacturer.

The clinical composition of the grafting material is an important aspect in osteoconduction, the more similar the material to the bone composition, the better the result ${ }^{3}$. Therefore, this could be a possible reason for a faster start of the healing process in the BB group.

The polyurethane was absorbed, replaced by bone and no pus or severe inflammatory reaction was observed. Deeper experimental and clinical evaluation is necessary to provide data about specific cell response to the polyurethane and in order to recommend its application in dental practice.

\section{CONCLUSION}

Considering the limitations and goals of the present study, it can be concluded that: 1) Both groups showed an increase in bone formation and cavity filling throughout the course of the experiment, though this process was faster in the demineralized bovine bone group; 2) Analyzing the histological results, both materials can be classified as biocompatible, since they were well osseointegrated and no capsule formation was observed.

\section{ACKNOWLEDGEMENTS}

The authors acknowledge Baumer for supplying bovine bone and Professor Gilberto Chiérice for providing Ricinnus Communis polyurethane. The authors are also grateful to Luis Antonio Potenza and Pedro Sérgio Simões for their technical assistance in all laboratory procedures. 


\section{REFERENCES}

1- Albrektsson T, Sennerby L. Direct bone anchorage of oral implants: clinical and experimental considerations of the concept of osseointegration. Int J Prosthodont. 1990;3:30-41.

2- Boyne PJ. Osseous reconstruction of the maxilla and the mandible: surgical techniques using titanium mesh and bone mineral. Chicago: Quintessence Publishing; 1997.

3- Cornell CN, Lane JM. Current understanding of osteoconduction in bone regeneration. Clin Orthop Relat Res. 1998;355:267-73.

4- Dahlin C, Linde A, Gottlow J, Nyman S. Healing of bone defects by guided tissue regeneration. Plast Reconstr Surg. 1988;81:672-6.

5- Henning E, John A, Lemm W, Buchert ES, Wick G, Gerlach K. Bioestability of polyurethanes. Z Exp Chir Transplant Kunstliche Organe. 1989;22:204-20.

6- Hürzeler MB, Kohal RJ, Naghshbandi J, Mota LF, Conrado J, Hutmacher D, et al. Evaluation of a new reabsorbable barrier to facilitate guided bone regeneration around exposed implant threads. An experimental study in the monkey. Int J Oral Maxillofac Surg. $1998 ; 27: 315-20$

7- Konig B Junior, Forger SE, Mascaro MB, Beck TJ. Biocompatibility of the polyurethane resin of the castor bean inserted into the alveolar bone of the dog. Anat Anz. 1999;181:581-4.

8- Lamano-Carvalho TL, Araújo CACA, Teófilo JM, Brentegani LG. Histologic and histometric evaluation of rat alveolar wound healing around polyurethane resin implants. Int J Oral Maxillofac Surg. $1997 ; 26: 149-52$

9- Lamano-Carvalho TL, Teófilo JM, Araújo CACA, Brentegani LG Chronology of rat alveolar healing following immediate implantation of Ricinnus communis polyurethane resin: histometric analysis in rats. J Biomed Mater Res. 1997;37:449-52.

10 - Pinholt EM, Bang G, Haanaes HR. Alveolar ridge augmentation in rats by Bio-Oss ${ }^{\circledR}$. Scand J Dent Res. 1991;99:154-61.

11 - Reddi AH, Wientroub S, Muthukumaran N. Biologic principles of bone induction. Orthop Clin North Am. 1987;18:207-12.

12- Schmitt JM, Buck DC, Joh S, Lynch S, Hollinger JO. Comparison of porous bone mineral and biologically active glass in critical-sized defects. J Periodontol. 1997;68:1043-53.

13- Skoglund A, Hising P, Young C. A clinical and histological examination in humans of the osseous response to implanted natural bone mineral. Int J Oral Maxillofac Implants. 1997;12:194-9.

14- Urist MR, Huo YK, Brownell AG, Hohl WG, Buyske J, Lietze A, et al. Purification of bone morphogenetic protein by hydroxyapatite chromatography. Proc Natl Acad Sci USA. 1984;81:371-5.

15 - Urist MR, Strates BS. Bone morphogenetic protein. J Dent Res. 1971;50:1392-406

16- Valentini P, Abensur D. Maxillary sinus floor elevation for implant placement with demineralized freeze-dried bone and bovine bone (Bio-Oss ${ }^{\circledR}$ ): a clinical study of 20 patients. Int J Periodontics Restorative Dent. 1997;17:233-41.

17- Wetzel AC, Stich H, Caffesse RG. Bone apposition onto oral implants in the sinus area filled with different grafting materials: a histological study in beagle dogs. Clin Oral Implants Res. 1995;6:15565 . 